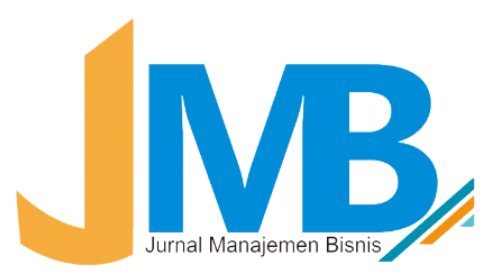

\title{
The Effect of Food Quality and Service Quality Towards Customer Satisfaction and Repurchase Intention (Case Study of Hot Plate Restaurants)
}

Desman Hidayat ${ }^{1}$, Aryo Bismo ${ }^{2}$, Amelia Ruwaida Basri $^{3}$

BINUS Entrepreneurship Center, Management Department, Bina Nusantara University, Jakarta, Indonesia ${ }^{1}$

Global Business Marketing Program, Management Department, BINUS Business School Undergraduate, Bina Nusantara University, Jakarta, Indonesia ${ }^{2,3}$

Corresponding Author's Email: d4906@binus.ac.id

Received:19-04-2020 | Revision: 11-07-2020| Accepted:15-07-2020

To cite this document:

Hidayat, D., Bismo, A., Basri, A.R., (2020) "The Effect of Food Quality and Service Quality Towards Customer Satisfaction and Repurchase Intention (Case Study of Hot Plate Restaurants)", Manajemen Bisnis, Vol. 10, No. 01, pp.01-09, http://ejournal.umm.ac.id/index.php/jmb/article/view/11913

\section{ABSTRACT}

The food and beverages industry have been growing rapidly, making the competition in this industry higher. Therefore, innovation is needed to survive. The purpose of this study is to analyze the influence of food quality and service quality on the customer satisfaction of hot plate restaurants' consumers, which in turn will have an impact on repurchase intention. The method used in this study is a quantitative approach, using a Likert Scale as a measurement method. Data analysis uses the structural equation modeling (SEM) method with SmartPLS 3.0 tools. The population of this study is XYZ hot plate restaurants' consumers in Sunter and Bekasi. Total sample that used in this research is 100 samples by using the Slovin formula. The results of this study show significant and positive effects, both individually and simultaneously, between food quality and service quality to customer satisfaction and its impact on repurchase intention. Therefore, in order to compete with others, XYZ hot plate restaurants should (1) Improve and maintain their foods and drinks, (2) Maintain their employees' credibility, and (3) Reduce the waiting list.

Keywords: food quality; service quality; customer satisfaction; repurchase intention

\section{INTRODUCTION}

In the era of globalization, businesses are developing in a rapid way. It can be seen from the economic growth in Indonesia. On 2017, the economic growth in Indonesia reached $5.07 \%$ and on the second quarter of 2018, it has raised $0.20 \%$ to $5.27 \%$ (Kompas.com, 2018). One of the industries that grows rapidly is the food and beverages industry. On 2016, there are 3,958 restaurants and cafes in Jakarta (Dinas Komunikasi, 
Informatika, dan Statistik Provinsi DKI Jakarta, 2018) and 2,853 restaurants and cafes in West Java (Badan Pusat Statistik Provinsi Jawa Barat, 2018). This shows that the competition in this industry is high. So, food and beverages business owners need to innovate more to attract customers while maintaining their customer satisfaction.

Several innovations can be done on food and beverages industry, e.g. serving fresh cooked food in front of their customers, or serving foods using hotplate. These innovations are especially good for millennials segment. Customer satisfaction is the standard on how the total products or services offered to meet the customers' expectation. Satisfied customers will have the intention to repurchase on the same restaurant. Berliansyah \& Suroso (2018) argue that repurchase intention is the consumer decision to involve in the activities with the service provider and other activities in the future. There are several factors that can improve customer satisfaction and purchase intention. Food quality and service quality are part of those factors. Food quality is the characteristics of the food that is acceptable by the consumers (Awi \& Chaipoopirutana, 2014), while service quality is the result of the difference between expectation of the quality and the actual quality performance (Al-Tit, 2015). This paper aims to find out (1) how food quality affects customer satisfaction; (2) how service quality affects customer satisfaction; (3) how customer satisfaction affects repurchase intention; (4) how food quality affects repurchase intention with customer satisfaction as the intervening variable; and (5) how service quality affects repurchase intention with customer satisfaction as the intervening variable.

\section{LITERATURE REVIEW}

Values that received by customers are the overall assessment between the products and services that received by the customer compared to what the costs they spent (Ahmad, Ghazali, Othman, \& Jules 2017). Zeithaml (1988) states that perceived value is defined as the overall assignment of the consumers on what they receive and what they give. Furthermore, he explained four types of values definition: (1) value is low price; (2) value is getting what the customers want from the product; (3) value is the quality that the customers get for the price they pay; (4) value is what the customer get for what they give. Tjiptono (2008) argues that quality is a dynamic condition that is related with products, services, human, processes, and environments that fulfill or surpass the expectation. Furthermore, conceptual product is a subjective understanding on something that is offered to reach the organization purpose by fulfilling the consumers' need and want, according to organizational competencies, capacities, and buying power. Product or food quality defined as the attempt to fulfill the consumers' need and want, also the right delivery to meet the consumers' expectation (Aminudin, 2015). Good quality food is food that serves well, fresh, and delicious (Ha \& Jang, 2012). There are four dimension of food quality (Qin, Prybutok, \& Zhao, 2010): fresh, presentation, well-cooked, and a variety of food and beverages. Service quality have five dimensions (Sugiyono, 2014): tangibles, reliability, responsiveness, assurance, and empathy. 
Customer satisfaction defines as post-purchase attitude determinant reflecting positive or negative result based on consumers' private experience (Canny, 2014). It is the fulfillment of the consumer response (Tharanikaran \& Thusyanthy, 2017). Hawkins \& Lonney cited by Tjiptono (2004) states three dimensions of customer satisfaction: satisfaction suitability, repurchase intention, and willingness to recommend. Repurchase intention represents the possibility of customers to involve in future behaviors, while the behaviors are the level of behavior observed objectively (Santoso, 2016). It is defined as the consumer intention to repurchase specific products or services in the future (Wang \& Yu, 2016). Ferdinand cited by Saidani \& Samsul (2012) states that there are four dimensions of repurchase intention: transactional intention, referential intention, preferential intention, and exploratory intention.

Product and service quality are highly connected with customer satisfaction and company profitability (Kotler \& Keller, 2016). In terms of restaurant, better food quality will give higher customer satisfaction. Likewise, better service quality will also give higher customer satisfaction. Therefore, the first hypothesis is food quality has significant effect on customer satisfaction, and the second hypothesis is service quality has significant effect on customer satisfaction Customer satisfaction are also related with repurchase intention (Putro, Semuel, \& Brahmana, 2014). The satisfaction of a brand can help to maintain long term relationship with the consumer of the brand. Those consumers will repurchase the brand since they believe it will satisfy their needs. Therefore, there is a positive effect of customer satisfaction to repurchase intention, which can be seen on the third hypothesis which is customer satisfaction has significant effect on repurchase intention

Good food and service quality that fulfill customer's expectation will lead to customer satisfaction (Awi and Chaipoopirutana, 2014). Food quality, service quality, and customer satisfaction all increase the customer's repurchase intention. Customers visit XYZ restaurant because XYZ restaurant able to fulfill customers' hope from the taste and the quality of their food, also the quality of their services. Therefore, the fourth hypothesis is food quality intervened by customer satisfaction has significant effect on repurchase intention, and the fifth hypothesis is service quality intervened by customer satisfaction has significant effect on repurchase intention. Based on the explanation of the proposing hypothesis on this research so the framework of this research can be seen on Figure 1: 


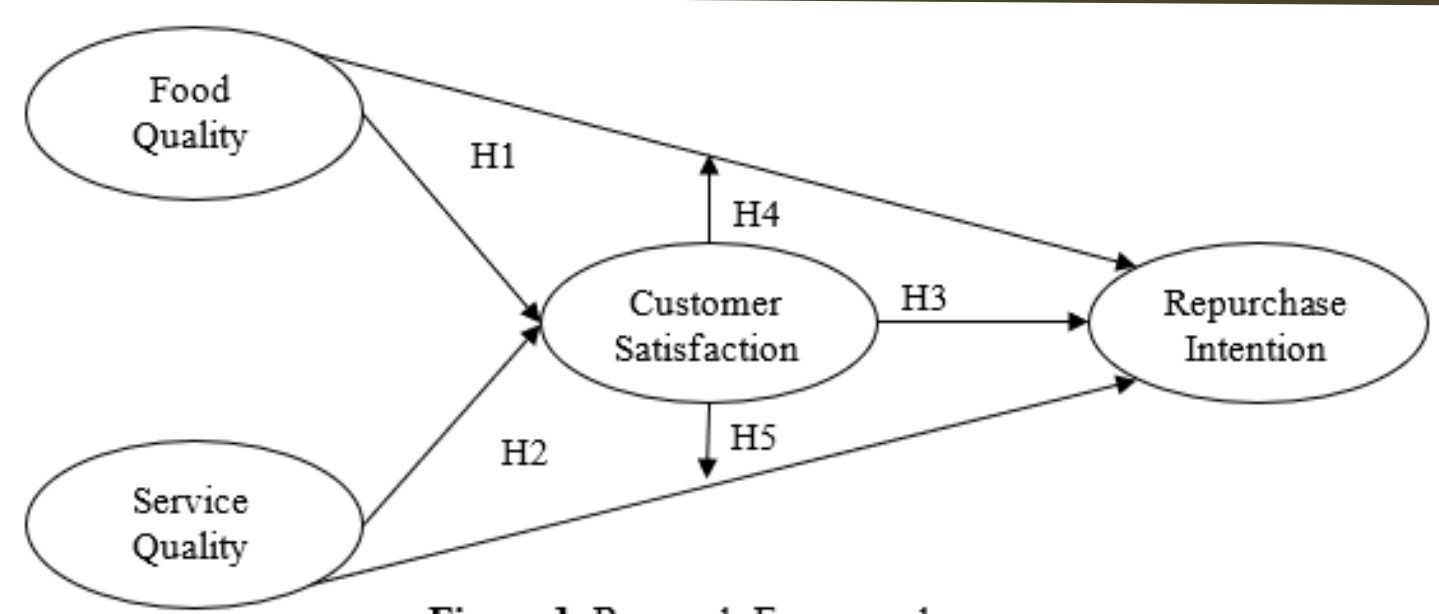

Figure 1. Research Framework

\section{RESEARCH METHOD}

This study uses quantitative approach. Quantitative approach is the research approach that emphasizes on the breadth of information and is suitable for big population with limited variables, with the results considered as the representation of the population (Sugiyono, 2014). Furthermore, Sugiyono (2014) defines population as the generalization domain that consists of objects or subjects with specific quality and characteristics that set by researchers in order to study and concludes. In this study, the population is the consumers of Hot Plate XYZ Restaurant at Sunter, Jakarta and Bekasi, West Java. Cooper $\&$ Schindler (2014) defines sample as a portion of the target population that must be carefully selected in order to represent that population. In this study, the samples are Hot Plate XYZ Restaurant consumers in Sunter and Bekasi, age 16-40 years old, with the status of students, employees, or entrepreneurs.

Questionnaires are filled by customers that purchase within 6 months on 2018 to 2019. The technique used for this study is simple random sampling because population is known. The total population is 1551 people. The degree of confidence for this study is $90 \%$ with the error rate $10 \%$. By using Slovin formula, the minimum sample needed for this study is 100 samples, with the formula as below:

$$
n=\frac{1.551}{1+1.551 \times 0,10^{2}}=99,93 \approx 100
$$

This study uses structural equation modelling (SEM) as the statistic technique. SEM is a multivariate statistic technique that combines factor analysis and regression analysis. SEM is used to test the relationship between variables in a research model (Ghozali and Latan, 2015). PLS-SEM is part of SEM that aims to test the predictive relationship between constructs by looking at the connection or effects between constructs. 


\section{RESULT AND DISCUSSION}

After passing validity and reliability test, this study continues with the next process, which is to test whether there is an effect between variables. The results from $\mathrm{R}$ Square test can be seen on Table 1:

Table 1. R Square

\begin{tabular}{lcc}
\hline & $\begin{array}{c}\mathrm{R} \\
\text { Square }\end{array}$ & $\begin{array}{c}\mathrm{R} \\
\text { Square } \\
\text { Adjusted }\end{array}$ \\
\hline $\mathrm{CS}$ & 0.695 & 0.688 \\
$\mathrm{RI}$ & 0.731 & 0.723 \\
\hline
\end{tabular}

From the output of R-Square, it can be concluded that the effect of food quality, service quality, and customer satisfaction towards repurchase intention is $73.1 \%$, while the food quality and service quality effect toward customer satisfaction is $69.5 \%$. The bootstrapping results can be seen on Figure 2:

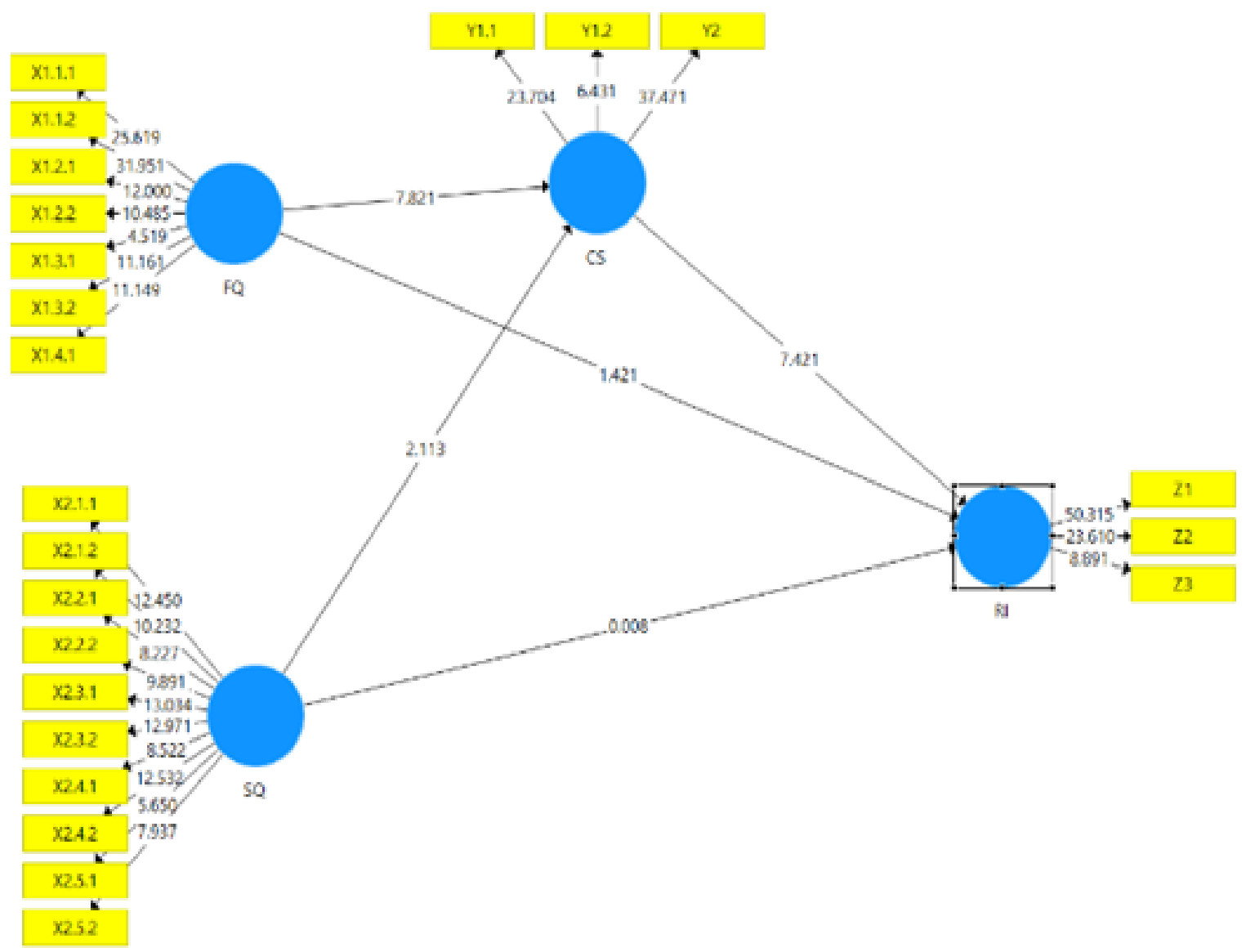

Figure 2. Bootstrapping Result 
The results of the hypothesis testing using path coefficient can be seen on Table 2, while the results for the indirect effect can be seen on Table 3 .

Table 2. Path Coefficient

\begin{tabular}{lccccc}
\hline & $\begin{array}{c}\text { Original } \\
\text { Sample } \\
(\mathrm{O})\end{array}$ & $\begin{array}{c}\text { Sample } \\
\text { Mean } \\
(\mathrm{M})\end{array}$ & $\begin{array}{c}\text { Standard } \\
\text { Deviation } \\
(\text { STDEV })\end{array}$ & $\begin{array}{c}\text { T Statistics } \\
(|\mathrm{O} / \mathrm{STDEV}|)\end{array}$ & P VALUES \\
\hline CS -> RI & 0.722 & 0.723 & 0.097 & 7.421 & 0.000 \\
FQ -> CS & 0.670 & 0.654 & 0.086 & 7.821 & 0.000 \\
FQ -> RI & 0.155 & 0.169 & 0.109 & 1.421 & 0.156 \\
SQ -> CS & 0.192 & 0.207 & 0.091 & 2.113 & 0.035 \\
SQ -> RI & 0.001 & -0.016 & 0.117 & 0.008 & 0.993 \\
\hline
\end{tabular}

Table 3. Indirect Effect

\begin{tabular}{lccccc}
\hline & $\begin{array}{c}\text { Original } \\
\text { Sample } \\
(\mathrm{O})\end{array}$ & $\begin{array}{c}\text { Sample } \\
\text { Mean } \\
(\mathrm{M})\end{array}$ & $\begin{array}{c}\text { Standard } \\
\text { Deviation } \\
(\text { STDEV })\end{array}$ & $\begin{array}{c}\text { T Statistics } \\
(|\mathrm{O} / \mathrm{STDEV}|)\end{array}$ & P VALUES \\
\hline FQ -> CS -> RI & 0.483 & 0.474 & 0.094 & 5.158 & 0.000 \\
SQ -> CS -> RI & 0.138 & 0.150 & 0.070 & 1.964 & 0.050 \\
\hline
\end{tabular}

Based on the results of data processing, it can be concluded that, there is a significant effect of food quality towards customer satisfaction on XYZ Hot Plate Restaurant consumers. So the hypothesis 1 of this research is accepted. This result confirms previous researches that showed how food quality can raise the customer satisfaction (Al-Tit, 2015; Berliansyah \& Suroso, 2018). Namkung \& Jang (2007) state that taste and presentation of the food are two of the major part that contributes to the customer satisfaction. Therefore, the manager should pay attention to food quality in order to raise the customer satisfaction.

Hypothesis 2 proves that there is a significant effect of service quality towards customer satisfaction on XYZ Hot Plate Restaurant consumers. This result also confirms previous studies done by Al-Tit (2015) and Izogo \& Ogba (2015) that argues service quality affects customer satisfaction. Qin \& Prybutok (2009) also support this argument and suggest that customer feedback about the service should be collected real time. Hypothesis 3 also proves that there is a significant effect of customer satisfaction towards repurchase intention on XYZ Hot Plate Restaurant consumers. The prove supports Awi \& Chaipoopirutana (2014) that argue to increase repurchase intention, business should focus on increasing their customer satisfaction. Mensah \& Mensah (2018) add that customer satisfaction and repurchase intention are important in order to increase the restaurant profit.

Berliansyah \& Suroso (2018) also argue that offering and selling high quality foods and drinks can increase customer satisfaction which increase repurchase intention. This argument also supported by hypothesis 4 and 5 that prove food quality and service quality 
as the intervening variable. Hypothesis 4 , there is a significant effect of food quality towards repurchase intention with customer satisfaction as the intervening variable on XYZ Hot Plate Restaurant consumers and the hypothesis 5, there is a significant effect of service quality towards repurchase intention with customer satisfaction as the intervening variable on XYZ Hot Plate Restaurant consumer.

\section{CONCLUSION}

This study has found that food quality and service quality have positive and significant impact on customer satisfaction of XYZ hot plat restaurant while customer satisfaction have positive and significant impact on repurchase intention. Food and service quality both have positive and significant impact indirectly on repurchase intention with the intervening of customer satisfaction.

This study provides several practical suggestions to XYZ hot plate restaurant: (1) XYZ hot plate restaurant should add more variations on its drinks, add more portion and maintain the hot plate temperature so that the food will not get burnt. (2) Maintain the employees' credibility that can be seen from the way they handle complaints and their hospitality when they greet the customers. (3) Need to add more tables and chairs to reduce the waiting list and choose more comfortable tables and chairs.

\section{REFERENCES}

Ahmad, F., Ghazali, H., Othman, M., \& Jules, N. J. (2017). Influence of Restaurant Attributes Towards Perceived Value and Customer. World Applied Sciences Journal, 33.

Al-Tit, A. (2015). The Effect of Service and Food Quality on Customer Satisfaction and Hence Customer Retention. Asian Social Science, 129-139.

Aminudin, L. (2015). Pengaruh Kualitas Produk, Promosi dan Store Atmosfir Terhadap Keputusan Pembelian Konsumen Pada KFC Mega Mas Manado. Jurnal Berkala Ilmiah Efisiensi, 703.

Awi, Y. L., \& Chaipoopirutana, S. (2014). A Study of Factors Affecting Consumer's Repurchase Intention toward Xyz Restaurant, Myanmar. International Conference on Trends in Economics, Humanities and Management, 181-184.

Badan Pusat Statistik Provinsi Jawa Barat (2018). Jumlah Restoran/Rumah Makan Menurut Kabupaten/Kota di Provinsi Jawa Barat, 2013-2016. Retrieved from https://jabar.bps.go.id/statictable/2018/03/23/472/jumlah-restoran-rumah-makanmenurut-kabupaten-kota-.html

Berliansyah, R. A., \& Suroso, A. (2018). The Influence of Food \& Beverage Quality, Service Quality, Place, and Perceived Price to Customer Satisfaction and Repurchase Intention. Journal of Research in Management, 1(1).

Canny, I. U. (2014). Measuring the Mediating Role of Dining Experience. International Journal of Innovation, Management and Technology, 25-26. 
Cooper, D. R., \& Schindler, P. S. (2014). Business Research Methods. The McGrawHill Companies.

Dinas Komunikasi, Informatika, dan Statistik Provinsi DKI Jakarta (2018). Data Usaha Jasa Makanan dan Minuman Jenis Usaha Restoran di DKI Jakarta. Retrieved from http://data.jakarta.go.id/dataset/data-usaha-jasa-makanan-dan-minumanjenis-usaha-restoran-di-dki-jakarta-20

Ghozali, I., \& Latan, H. (2015). Partial Least Squares Konsep, Teknik dan Aplikasi. Semarang: Undip.

Ha, J., \& Jang, S. S. (2012). The effects of dining atmospherics on behavioral intentions through quality perception. Journal of Services Marketing.

Izogo, E. E., \& Ogba, I. E. (2015). Service quality, customer satisfaction and loyalty in automobile repair services sector. International Journal of Quality \& Reliability Management.

Kompas.com. (2018). Pertumbuhan Ekonomi Kuartal II 2018 Tertinggi Sejak 2014. Retrieved from https://ekonomi.kompas.com/read/2018/08/07/102100026/pertumbuhan-ekonomikuartal-ii-2018-tertinggi-sejak-2014.

Kotler, P., \& Keller, K. L. (2016). Marketing management (15th global ed.). England: Pearson.

Mensah, I., \& Mensah, R. D. (2018). Effects of Service Quality and Customer Satisfaction on Repurchase Intention in Restaurants on University of Cape Coast Campus. Journal of Tourism, Heritage \& Services Marketing, 4(2), 27-36.

Namkung, Y., \& Jang, S. (2007). Does food quality really matter in restaurants? Its impact on customer satisfaction and behavioral intentions. Journal of Hospitality \& Tourism Research, 31(3), 387-409.

Putro, S. W., Semuel, H., \& Brahmana, R. K. (2014). Pengaruh Kualitas Layanan Dan Kualitas Produk Terhadap Kepuasan Pelanggan Dan Loyalitas Konsumen Restoran Happy Garden Surabaya. Jurnal Manajemen Pemasaran Vol.2, No. 1, 19.

Qin, H., \& Prybutok, V. R. (2009). Service quality, customer satisfaction, and behavioral intentions in fast-food restaurants. International Journal of Quality and Service Sciences.

Qin, H., Prybutok, V. R., \& Zhao, Q. (2010). Perceived service quality in fast-food restaurants: Empirical evidence from China. International Journal of Quality \& Reliability Management.

Saidani, B. \& Samsul, A. (2012). Pengaruh Kualitas Produk dan Kualitas Layanan Terhadap Kepuasan Konsumen dan Minat Beli Pada Ranch Market. Jurnal Riset Manajemen Sains Indonesia (JRMSI), Vol. 3, No. 1, 2012

Santoso, J. E. (2016). Pengaruh Food Quality, Service Quality, Price Promotion, Dan Customer Satisfaction Terhadap Repeat Purchase Intention Restoran Solaria. Jurnal Bisnis Dan Manajemen, 71.

Sugiyono, P. D. (2014). Metode Penelitian Manajemen. Yogyakarta: Alfabeta, CV. 
Tharanikaran, V., \& Thusyanthy, V. (2017). Antecedents and Outcomes of Customer Satisfaction: A. International Journal of Business and Management, 145.

Tjiptono, F. (2004). Manajemen Jasa. Yogyakarta: Andi

Tjiptono, F. (2008). Strategi Pemasaran, 3rd Edition. Yogyakarta: Andi

Wang, E. S.-T., \& Yu, W. J.-R. (2016). Effect of product attribute beliefs of ready-todrink coffee beverages on consumer-perceived value. British Food Journal.

Zeithaml, V. A. (1988). Consumer perceptions of price, quality, and value: a means-end model and synthesis of evidence. Journal of marketing, 52(3), 2-22. 